\title{
Restructuring as the Tool of Competitiveness of the Defense and Industrial Complex
}

\author{
${ }^{1}$ Anna A. Bakulina, ${ }^{2}$ Vladimir I. Avdisky, ${ }^{3}$ Vladimir V. Zemskov \\ ${ }^{1}$ Doctor of Economics, Associate Professor, Vice-Rector Deputy for Research, Professor of the Department of \\ Corporate Finance and Corporate Governance, FSEBU HE "Financial University under the Government of the \\ Russian Federation" \\ ${ }^{2}$ Doctor of Law, Prof, The Dean of Risk Analysis and Economic Security Faculty, FSEBU HE "Financial \\ University under the Government of Russian Federation" named after V.K. Senchagov \\ ${ }^{3}$ Doctor of Economics, Professor of the Department "Risk Analysis and Economic Security", FSEBU HE "Financial \\ University under the Government of Russian Federation" \\ Email: zemskov58@list.ru
}

Received: 22 ${ }^{\text {nd }}$ June 2018, Accepted: 01 ${ }^{\text {st }}$ August 2018, Published: $31^{\text {st }}$ August 2018

\begin{abstract}
In our country, the intensification of crisis phenomena continues. A significant number of strategic enterprises and organizations of the defense and industry complex, work in crisis conditions and are unprofitable. The main reasons for the loss are high production costs, the technological backwardness of production and the physical depreciation of fixed assets. The article examines the measures of state support aimed at the development of a set of measures to restructure industrial capacities, as well as other measures that contribute to the restoration of production capacities for the production of competitive military products. It was noted that state support made a positive effect on the financial condition of strategic enterprises and the organizations of the defense industry complex from the granting of subsidies to the implementation of the state defense order.
\end{abstract}

Keywords: State Support, Subsidy, Property Rights of Russian Federation, The Restructuring of Industrial Capacities, Competitiveness.

\section{On the Problem of Industrial Capacity Restructuring \\ In modern Russia, the restructuring of strategic enterprises and organizations of the defense industry complex (hereinafter - the enterprises of the DIC) is an indispensable element of strategic planning. Restructuring ensures the compliance with the balance of interests of a state on behalf of an authorized federal executive body and DIC enterprises and, as a result, the achievement of sustainable development trajectory in a strategic perspective. The restructuring of domestic industrial enterprises, conducted in the early nineties of the last century, was not successful and effective, which led to the development of a large number of unprofitable enterprises on the verge of bankruptcy.}

Within the conditions of changing internal and external environment for doing business, DIC enterprises should make timely changes in their economic activities for the organization of competitive production, taking into account modern requirements, i.e. to restructure.

According to the Concept of Sector Restructuring Program Development ${ }^{2}$, approved earlier by the authorized executive body, the main tasks of restructuring is the attraction of credit and investment resources, the search for partners in business, the expansion and the consolidation of production, the introduction of new technologies, the diversification and the demonopolization of production, and the fragmentation of the property complex into individual enterprises.

The same position was held by A.I. Ilchenko and Rychikhina I.S., considering that the restructuring of an enterprise is a controlled process of economic activity structure changing (assets, property, finance, management, personnel, etc.) in order to adapt the internal structure of an enterprise to the constantly changing conditions of the external environment to achieve enterprise sustainability [1].

Thus, the restructuring of industrial capacities in the DIC is the implementation of production, technical, organizational and other measures aimed at the output of competitive product volume and DIC economic potential increase.

In this regard, the improvement of DIC enterprise restructuring process is an important and strategic task, representing both theoretical and great practical interest.

\section{Evolution of DIC Restructuring Processes}

DIC enterprises have passed several stages of industrial capacity restructuring in the course of their development.

At the first restructuring stage, unitary enterprises were created, through which the state participated in economic activities. A unitary enterprise is a commercial organization that is not endowed with the 
right to own property assigned to it by an owner. The property of a unitary enterprise is indivisible and can not be distributed among deposits, also between enterprise employees. State and municipal enterprises operate in the organizational and legal form of unitary enterprises. $^{2}$

The regulation of economic activity was carried out on the basis of the Federal Law No. 161-FL "On State and Municipal Unitary Enterprises" issued on 14.11.2002. It should be noted that the indivisibility of a unitary enterprise property was confirmed by the creation of a statutory fund, and not an authorized capital. The development of a statutory fund was regulated by the Order of the Ministry of Economic Development No. 205 "On the Approval of the Model Charter of the Federal State Unitary Enterprise based on the right of economic management" issued on 25.08.2005.

Practice has shown that unitary enterprises could not manage effectively the received property and should be transformed into other organizational and legal forms of a legal entity in the future, which is reflected in the Concept of RF Civil Legislation development. ${ }^{3}$ The second stage of restructuring is characterized by the transformation of unitary enterprises into open joint-stock companies. The main normative document regulating the transformation of unitary enterprises into the organizations of other organizational and legal forms is the Federal Law No. 178-FL "On the Privatization of State and Municipal Property" issued on December 21, 2001. In accordance with the subparagraph 1 of paragraph 1 of the Article 13 of Law No. 178-FL, the transformation of a unitary enterprise into a joint-stock company is one of the ways to privatize state and municipal property.

In the course of privatization, an owner of the property determines the composition of the property complex of a unitary enterprise subject to privatization in a transfer act, approves the company charter and determines the number of the board of directors members (supervisory board) and appoints the members of the board of directors (supervisory board) and its chairman, appoints the members of the audit commission.

At the same time, the privatization of unitary enterprises included in the List of Strategic Enterprises2 was carried out through the property contribution to newly created strategic joint-stock companies.

By Russian Federation Government Resolution No. 1226-r issued on August 20, 2009 they approved the strategic joint-stock companies whose shares are in federal ownership and the participation of Russian Federation, ensures strategic interests, defense capability and state security by their management.

The result of state property privatization was the appearance of new business entities on the markets (vertically integrated structures) with the corresponding rights and responsibilities accountable to state corporations. For the first time the term "state corporation" appeared in Russia in 1999 due to the creation of "The Agency for Credit Organization Restructuring" in the form of a non-commercial organization created and a state corporation by Russian Federation to restore the solvency of credit institutions.

According to the Article 7.1 of the Federal Law No. 7FL "On Non-Profit Organizations" issued on 12.01.1996, a state corporation is a non-profit organization established by Russian Federation on the basis of a property contribution and created for the implementation of social, managerial or other socially useful functions. A state corporation is created on the basis of the federal law.

State corporations were widely recognized as business entities in 2007 due to the adoption of separate federal laws regulating the activities of these entities.

\begin{tabular}{|l|c|}
\hline List of laws & $\begin{array}{l}\text { The number of } \\
\text { DIC enterprises }\end{array}$ \\
\hline $\begin{array}{l}\text { Federal Law No. 270-FL "On } \\
\text { the State Corporation } \\
\text { "Rostekh" " issued on } \\
23.11 .2007\end{array}$ & More than 700 \\
\hline $\begin{array}{l}\text { Federal Law No. 317-FL "On } \\
\text { the State Atomic Energy } \\
\text { Corporation "Rosatom" " issued } \\
\text { on December 1, 2007 }\end{array}$ & \\
\hline $\begin{array}{l}\text { Federal Law No. 215-FL "On } \\
\text { the State Corporation for }\end{array}$ & \\
$\begin{array}{l}\text { Space Activities "Roskosmos" } \\
\text { " issued on July 13, 2015 }\end{array}$ & \\
\hline
\end{tabular}

Table 1. The List of State Corporations in the DIC As can be seen from Table 1, the largest state corporation is "Rostekh", established for the purpose of development, production and exportation of hightech industrial products, the control loop of which includes more than 700 of strategic joint-stock companies.

"Rosatom" State Corporation is a vertically integrated structure (holding) that owns the assets and the competencies in all segments of the production and technological chain of nuclear energy: geological prospecting and uranium mining, uranium conversion and enrichment, the fabrication of nuclear fuel, engineering, design and construction of nuclear power plants, the generation of electric power energy, the decommissioning of nuclear facilities, the management of spent nuclear fuel and radioactive waste. 
The main objective of "Roskosmos" is the implementation of the state policy in the field of space activity and its regulatory and legal regulation, as well as the placement of orders for the development, production and supply of space technology and space infrastructure facilities.

The third stage of restructuring is characterized by further improvement of economic activity structure with the aim of an optimal organizational structure achievement and the introduction of corporate governance world practices.

Further improvement of economic activity structure is considered in the integration of risk management system with key business processes, including strategic planning, investment planning, internal control, and the wider use of risk analysis tools in the situations of key management decisions.

At this stage, in order to manage assets and liabilities effectively, the main corporate rule was the development of consolidated financial statements according to the requirements of International Financial Reporting Standards (IFRS).

Also, the asset corporate governance system is being improved - through the creation of a mechanism for trust management by holding assets, divided into strategic, investment and operational models of corporate governance with the transfer of shares of key production assets as a property contribution of Russian Federation.

It should be noted that the main contribution to improve the competitiveness of the defense industry sectors falls on the state program for the development of armaments in 2016-2020, 1 trillion 67 million rubles of budgetary allocations will be sent for its implementation, while the share of the innovative products should be $40 \%$ of the total output. 2

A major role in economic potential of defense industry enterprise improvement is played by the implementation of federal target programs "The Development of Russian Federation Defense Industry Complex in 2011-2020" (FTP), which ensure the country defense capability increase by securing and retaining of highly qualified experts, as well as by the introduction of new technologies that meet modern business requirements.

Military-technical cooperation (MTC) with the CIS countries, BRICS and with the countries of the Asian region plays an important role for a sustainable development provision of the military industrial complex. At that, the cooperation in the sphere of MTC between DIC enterprises and foreign customers is carried out through "Rosobor on export".

DIC Restructuring Ways in Modern Conditions

The main goal of the majority of DIC restructuring is to increase the capitalized value of an enterprise. However, in recent years, the sanctions imposed by
Western countries and the United States on the limitation of military product export and the admission to the global financial market made a negative impact on the increase of DIC enterprise capitalized value.

Taking into account the current situation, it is necessary to solve a complex of organizational and financial measures aimed at the stabilization of DIC economics by seeking internal resources. A list of priority measures with a stabilizing importance for DIC economics is proposed.

First, it is necessary to consider whether it is advisable to establish a trust fund for state corporation funds by channeling the part of the profits received for the implementation of relevant measures to modernize the industrial capacities of DIC. The funds from this trust fund can be allocated both on a returnable and irretrievable basis to solve strategic tasks.

Secondly, in accordance with the paragraph 4 of the Article 15 of the Federal Law No. 127-FL "On Science and State Scientific and Technical Policy" issued on 23.08.1996, the financial support for scientific, scientific and technical, innovative activities can be provided by state funds to support scientific, technical and innovative activities created in accordance with the legislation of Russian Federation and the legislation of the constituent entities of RF, as well as by the funds for the support of scientific, scientific and technical, innovative activities, established by legal entities and (or) individuals.

Therefore, it would be possible to form scientific foundations at the expense of the corresponding deductions from DIC enterprises, at that these deductions form a taxable base for income tax.

Thirdly, it is necessary to launch a procedure to improve the tax legislation of Russian Federation with regard to the taxation of DIC enterprise activities. On 1 January 2013, in accordance with the subparagraph 1 of the paragraph 1 of the Article 394 of RF Tax Code, tax rates may not exceed 0.3 percent for land plots restricted in turnover and in accordance with the legislation of Russian Federation provided for defense, security and customs needs.

At the same time, from the content of paragraph 5 of the Article 27 of the Land Code, it follows that the restriction of land plots in turnover is related to the category of land allowed for use, as well as the actual use of the land for defense, security and customs purposes.

It should be noted that for the purpose of defense, land plots may be granted for the needs provided by the paragraph 2 of the Article 93 of the Land Code. For the assignment of a land plot to the lands granted for security and customs needs, it is of fundamental importance to use it to support the activities provided by Federal Law No. 390-FL "On Security" issued on December 28, 2010, Federal Law No. 311-FL "On 
customs regulation in Russian Federation" issued on November 27, 2010, respectively.

At the same time, there are no documents confirming the assignment of a land plot to the lands withdrawn from circulation or limited in turnover, according to the current legislation of Russian Federation.

During the transformation of federal state unitary enterprises into strategic joint-stock companies, the enterprises of DIC acquired THE land plots of large sizes, the areas of which are normatively established proceeding from the specifics of production. At the same time, the norms of the subparagraph fourth of the first paragraph of the Article 394 of RF Tax Code ceased to apply to these land plots, since in accordance with the paragraph 5 of the Article 27 of RF Land Code, the land plots in state or municipal ownership are restricted in circulation.

Consequently, after the privatization DIC enterprises became the taxpayers of land tax, the tax rate on which can not exceed 1.5 percent of the cadastral value of land, in accordance with the paragraph 1 of the Article 394 of the Tax Code.

As was noted above, the plots used for defense needs has the status of limited turnover only on the condition that they are in state or municipal ownership.

There is a positive arbitration practice on the validity of land tax rate use by DIC enterprises within $0.3 \%$ of the cadastral value on the basis of abstract 5 of subpar. 1, par. 1 of the Article 344 of RF Tax Code (Definition of RF Supreme Court №301-KG14 -8352 issued on 03.03.2015).

\begin{tabular}{|c|c|c|c|c|c|c|c|}
\hline Name & USA & China & $\begin{array}{l}5 \text { countries } \\
\text { of Western } \\
\text { Europe }\end{array}$ & India & Brazil & $\begin{array}{c}\text { Czech } \\
\text { Republic }\end{array}$ & Russia \\
\hline $\begin{array}{l}\text { Household } \\
\text { expenditures in the } \\
\text { digital sphere }\end{array}$ & 5,3 & 4,8 & 3,7 & 3,2 & 2,7 & 2,2 & 2,6 \\
\hline $\begin{array}{l}\text { Company investments } \\
\text { in digitalization }\end{array}$ & 5,0 & 1,8 & 3,9 & 2,7 & 3,6 & 2,0 & 2,2 \\
\hline $\begin{array}{l}\text { Public expenditure on } \\
\text { digitalization }\end{array}$ & 1,3 & 0,4 & 1,0 & 0,6 & 0,8 & 0,5 & 0,5 \\
\hline ICT export & 1,4 & 5,8 & 2,5 & 5,9 & 0,1 & 2,9 & 0,5 \\
\hline ICT import & $-2,1$ & $-2,7$ & $-2,9$ & $-6,1$ & $-1,0$ & $-2,1$ & $-1,8$ \\
\hline $\begin{array}{l}\text { The total share of the } \\
\text { digital economy in GDP }\end{array}$ & 10,9 & 10,0 & 8,2 & 6,3 & 6,2 & 5,5 & 3,9 \\
\hline
\end{tabular}

\section{Table 2: The Contribution of Digital Economy to the GDP of Some Countries in 2015, \% to GDP}

Nowadays, about $70 \%$ of GDP of Russia is formed by the companies with state participation and state and municipal bodies, which are the basic vector of Russia economic potential development. ${ }^{3}$
The released funds could be used for the modernization of the defense industry complex and the implementation of federal target programs, the renewal of the production base, the creation of quality additional jobs in the organizations of Russian Federation defense industry.

On the basis of the foregoing, it is proposed to supplement the subparagraph 1 of the first paragraph of the Article 394 of RF Tax Code with the rules on a tax rate application not exceeding 0.3 percent in respect of land plots of military-industrial complex organizations.

Fourthly, to use the infrastructure of the digital economy2. By digital economy we mean "the type of management characterized by the predominant role of data and their management methods as a determining resource in production, distribution, exchange and consumption" [2].

The development of the digital economy intensifies, both in Russia and in other countries of the world. The leaders in the development of the digital economy are the United States, where the share of the digital economy in the country GDP is $10.9 \%$, followed by China (10\% in the country GDP), the European Union (table 1). In Russia, the share of digital economy currently makes up $3.9 \%$ of GDP, and within the framework of the program "Digital economy development in Russia until 2035" it is planned to increase it to $8-10 \%$ of GDP. 
upgrade the capacities of DIC to produce civilian products, which will positively affect the competitiveness of DIC.

According to the forecasts of RF Ministry of Industry and Trade, the growth of civil product output by DIC enterprises is planned to be 1.3 times by 2020 . They plan to ensure a significant jump in production by the mass production of new passenger aircraft of different classes: MS-21, IL-114-300, IL-112V, Tu-334, Tu214 and Tu-204. It is expected that by 2025 the number of passenger aircraft produced in the country will grow 3.5 times - from 30 to 110 airplanes per year.

The scientific and technical reserve created in 20022008 was used in the program for the fifth generation basic engine development PD-14. During the period of 2002-2015, within the framework of the program, various classes of materials and technologies for their use in aviation structures were developed.

\section{Conclusions}

At the present stage of the country development, DIC enterprises have significant resources necessary for a sustainable development of DIC sectors. It is noted that one of the tools of sustainable development is the restructuring of capacities that allow the economy to be transferred for the production of competitive military and civilian products.

In these conditions, the digitalization of DIC sectors will ensure the creation of innovative products with a high level of added value.

\section{References}

1. Ilchenko A.I., Rychikhina I.S. Indicative method of enterprise needs determination in restructuring // Economic analysis: theory and practice. - M.: "Finance and Credit" PH. - 2006. - No. 20.

2. Semyachkov K.A. Digital economy and its role in the management of modern socio-economic relations // Modern management technologies. 2017. № 8 (80).

3. Kharchenko A.A., Konyukhov V.Yu. Digital Economy as the Future Economy // The Youth Bulletin of the Irkutsk State Technical University. 2017. No. 3 (27). p. 17.The state and state companies control $70 \%$ of the Russian economy /I

Vedomosti.

URL:www.vedomosti.ru/economics/articles/201

6/09/29/658959-goskompanii-kontroliruyut-

ekonomiki. 